\title{
Effects of the Ayurved Siriraj Wattana recipe on functional and phenotypic characterization of cytokine-induced killer cells and dendritic cells in vitro
}

\author{
Adisak Wongkajornsilp', Nuntarak Numchaisermsuk1, Khanit Sa-ngiamsuntorn", Pravit Akarasereenont 1,2, \\ Valla Wamanuttajinda', Kanda Kasetsinsombat ${ }^{1}$, Sunisa Duangsa-ard ${ }^{1}$, Tawee Laohapan ${ }^{2}$ and \\ Kittipong Maneechotesuwan ${ }^{3^{*}}$ (D)
}

\begin{abstract}
Background: Ayurved Siriraj Wattana recipe (AVS073), has been prescribed as tonic, to increase appetite, and for pain relief. It also exhibits antioxidant, anti-inflammatory, immunomodulating and anti-cancer activities. However, the immunomodulatory effects on antigen-presenting cells and effector T cells remained elusive. We thus aimed to study the effects of AVS073 on differentiation, maturation, functions and proportions of CIK cells and monocyte-derived DCs.

Methods: CIK cells and monocyte-derived DCs were treated with AVS073, followed by the assessment of T-helper (Th) phenotypes using real-time RT-PCR and flow cytometry.

Results: AVS073 promoted Th1 phenotype in $\mathrm{CD}^{+} \mathrm{CD}^{2} 6^{+}$subset of CIK cells through increasing STAT4, T-bet, and interferon- $\gamma$. AVS073 inhibited Th2 phenotype through decreasing STAT6. AVS073 inhibited Treg phenotype through decreasing STAT5A, STAT5B and IDO. AVS073 promoted Th17 phenotype through increasing STAT3, RORC and IL-17. AVS073 treatment of mDCs resulted in increasing Th1-prone cytokine (IL-12) and Th17-prone cytokines (IL-6 and IL-23).
\end{abstract}

Conclusions: AVS073 upregulated Th1 and Th17, but downregulated Th2 and Treg phenotypes within CD3 ${ }^{+} \mathrm{CD}_{56}{ }^{+}$cells. The treatment of $\mathrm{mDC}$ drove Th1 and Th17-polarizations.

Keywords: CIK cells, Dendritic cells, Lymphocytes, Traditional medicine Asia, Immunomodulation, Cytotoxicity

\section{Background}

Ayurved Siriraj Wattana recipe (AVS073) [1] has been used in Thai traditional medicine for decades. The recipe was prescribed for health promotion, strength supplement, appetite induction and attenuation of degeneration (anti-aging). It has recently been tested for immunomodulatory activity (NK cells activity), osteoarthritis and gastric emptying rate [2-4]. It conveyed protection against UVA-induced melanogenesis through an antioxidant/redox mechanism [1]. The 18 medicinal

\footnotetext{
* Correspondence: kittipong.man@mahidol.ac.th

${ }^{3}$ Department of Medicine, Faculty of Medicine Siriraj Hospital, Mahidol University, 2 Wanglang Road, Bangkoknoi, Bangkok 10700, Thailand

Full list of author information is available at the end of the article
}

plant components of the recipe are Aegle marmelos (L.) Corrêa., Boesenbergia rotunda (L.) Mansf., Caesalpinia sappan L., Carthamus tinctorius L., Cinnamomum siamense Craib, Citrus sinensis L.Osbeck, Cladogynos orientalis Zipp. ex Span., Cryptolepis buchanani Roem. \& Schult., Cyperus rotundus L., Derris scandens (Roxb.) Benth., Drypetes roxburghii Wall., Ferula assa-foetida L., Ligusticum sinense Oliv., Mallotus repandus (Willd.) Müll.Arg., Piper nigrum L., Saussurea lappa (Decne.) Sch.Bip., Terminalia chebula Retz., Tinospora crispa (L.) Hook. f. \& Thomson.

Aegle marmelos (L.) Corrêa has been used in the treatment of chronic diarrhea, peptic ulcers and dysentery, as a laxative and to recuperate from respiratory affections 
in various traditional medicines $[5,6]$. Boesenbergia rotunda (L.) Mansf has been commonly used in Southeast Asia as a food ingredient. Traditional healers throughout Thailand have been using this plant against inflammation, aphthous ulcer, dry mouth, stomach discomfort, dysentery, oral disease and cancers [7-9]. The heartwood of Caesalpinia sappan L. has been used as a hemostatic, analgesic and anti-inflammatory for traumatic disease and blood flow promoting agent [10-13]. Carthamus tinctorius L. has various pharmacological effects, e.g., anticoagulant and antithrombotic activities, anti-fibrotic effect, immunomodulatory activity [14-16]. The stem of Cryptolepis buchanani Roem. \& Schult. has been used for the treatment of inflammation, including muscle and joint pain [17-19]. Cyperus rotundus L. has antidepressant [20] and anti-melanogenesis activities [21]. Tinospora crispa (L.) Hook. f. \& Thomson has immunostimulatory effect [22, 23]. The other plant components in AVS073 also have anti-inflammatory effect and analgesic activity [24-30]. Some components of AVS073 showed direct anti-cancer properties through inhibiting cell growth or inducing cellular apoptosis, and indirect pathway via the immunological action of immune cells [31, 32]. Several in vitro and in vivo studies demonstrated that the extracts of AVS073's components carried antioxidant, anti-inflammatory, immunomodulating and anti-cancer actions [33-40].

Differentiation of Th1 cells are driven by STAT1 and STAT4 while STAT6 and GATA3 induces Th2 cells, forkhead transcription factor (Foxp3) induces regulatory $\mathrm{T}$ (Treg) cells, and retinoic acid-related orphan receptor (Rorc) induces Th17 cells [41]. Differentiation of Th1 cell and regulatory $\mathrm{T}$ (Treg) cells may be actually linked to the differentiation of Th2 and Th17, respectively, depending on the overall cytokine milieu. The differentiation of both Treg and Th17 cells requires TGF- $\beta$. The differentiation of Th17 cells requires low concentrations of TGF- $\beta$ in combination with the pro-inflammatory cytokines IL-6 and IL-23 [42], while in the absence of pro-inflammatory cytokines, high concentrations of TGF$\beta$ is optimal for Foxp3 expression and thus tips the balance towards Treg cell differentiation [43, 44]. In addition to cytokine environment, Treg cell development could be enhanced by kynurenine [45], a breakdown product of indoleamine 2, 3-dioxygenase (IDO) in dendritic cells (DCs).

DCs are professional antigen presenting cells that present antigens to naïve $\mathrm{T}$ cells, inducing their differentiation towards either Th1 or Th2 phenotype. DCs that generate Th1 responses would handle infections or malignant disorders via the induction of Th1-polarizing cytokine interleukin-12 (IL-12) and interferon-gamma (IFN- $\gamma$ ) [31]. In addition, Th17 cells also play a role in anti-tumor immunity [46]. In contrast, induction of Th2 responses by DCs may provide clinical benefits when Th1 responses are excessive, e.g., transplantation, contract allergy, or autoimmune disorders, by producing Th2 cytokines in particular IL-4, to induce B cells to secrete protective antibodies [47]. Immature DCs can be differentiated from monocytes and bone marrow progenitor cells by treatment with granulocyte macrophage colony-stimulating factor (GM-CSF) and IL-4. Immature DCs are stimulated with maturation signals, such as tumor necrosis factor $\alpha$ (TNF- $\alpha$ ), to express a strong immune response against foreign antigens. The exposure of cytokine-induced killer (CIK) cells to mature DCs led to the enhancement of anti-tumor cytolytic activity of the former [48-50].

A number of studies showed the possible immunological action of AVS073's components in DCs. Carthamus tinctorius L. extract has been reported to stimulate the production of IFN- $\gamma$ and IL-10 in mouse splenic T lymphocytes and promote the expression of maturation markers in mouse bone-marrow-derived DCs. Furthermore, Carthamus tinctorius L. treated DCs maintained the high profile of maturation markers in tumor antigen pulsed-DCs [31]. In contrast, Piper nigrum L. significantly inhibited the phenotypic maturation, cytokine production (TNF- $\alpha$ and IL-12), phosphorylation of ERK and JNK, but enhanced the endocytosis activity of LPSinduced bone-marrow-derived DCs [32]. DCs, which can subsequently interact with CIK cells $[49,51]$, might be potential targets of this recipe.

CIK cells have been used as non-major histocompatibility complex (MHC)-restricted effector cells with high cytotoxicity against a variety of tumor targets [52]. CIK could be driven toward Th1 phenotype away from Th2 phenotype, but no data for Treg and Th17 polarization [49]. However, there was no data available for the effect of AVS073 components on CIK cells. We investigated the alteration to Th-polarizing cytokine profiles in DCs and Th polarization in CIK cells after AVS073 treatment.

\section{Methods \\ Preparation of Ayurved Siriraj Watana Recipe powder}

The Ayurved Siriraj Watana Recipe was manufactured as powder under GMP Guidelines by the Center of Applied Thai Traditional Medicine, Faculty of Medicine Siriraj Hospital, Mahidol University. The sources of all herbal components came from the wild stretching from the Central and the Northeastern parts of Thailand. They were authenticated by experts, including certified pharmacognosists of the Center of applied Thai traditional medicine. Herbal raw materials were washed and dried in a hot air oven in accordance with the Ayurved Siriraj Watana Recipe Master Formula. It was validated with chemical fingerprint using ultra-performance liquid chromatography as previously described [1]. The crude 
powder was preserved at $25{ }^{\circ} \mathrm{C}$ in a desiccator. To prepare the extract, the crude powder was dissolved in $80 \%$ ethanol at a final concentration $100 \mathrm{mg} / \mathrm{mL}$. The extract was filtered with cotton wool and subsequently centrifuged at $10,000 \times \mathrm{g}$ for $10 \mathrm{~min}$. The supernatant was evaporated and lyophilized to dry powder.

\section{Generation of CIK cells and DCs from peripheral blood mononuclear cells}

CIK cells and DCs were generated from peripheral blood mononuclear cells (PBMCs) of healthy donors and characterized as described previously [49-51]. All healthy donor volunteers understood and signed the informed consent document before the participation. The protocol was approved by the Institutional Review Board of the Faculty of Medicine Siriraj Hospital, Mahidol University. PBMCs were isolated from whole blood by Ficoll gradient centrifugation (IsoPrep ${ }^{\circ}$, Robbins Scientific, CA). The cell suspension was allowed to adhere over the container at a density of $5 \times 10^{6}$ cells $/ \mathrm{mL}$ for $1 \mathrm{~h}$ at $37^{\circ} \mathrm{C}$ in RPMI 1640, 10\% FBS, $100 \mathrm{U} / \mathrm{mL}$ penicillin, and $100 \mu \mathrm{g} /$ $\mathrm{mL}$ streptomycin. The non-adherent cells (PBLs) were processed into CIK cells. The adherent cells were processed into mature DCs (mDCs) (Additional file 1).

To generate CIK cells, PBLs were maintained in RPMI 1640 (Invitrogen, Carlsbad, CA), 10\% FBS (Biochrom, Berlin, Germany), $100 \mathrm{U} / \mathrm{mL}$ penicillin and $100 \mu \mathrm{g} / \mathrm{mL}$ streptomycin. IFN- $\gamma$ (1000 U/mL, Amoytop Biotech, Xiamen, China) was added and incubated at $37{ }^{\circ} \mathrm{C}, 5 \%$ $\mathrm{CO}_{2}$ for $24 \mathrm{~h}$. After 24-h incubation, $50 \mathrm{ng} / \mathrm{mL}$ monoclonal antibody against CD3 (eBioscience, CA), and 300 IU/mL IL-2 (Amoytop Biotech, Xiamen, China) were added. Recombinant IL-2 and fresh growth medium were added every $3 \mathrm{~d}$. After $14 \mathrm{~d}$, AVS073 were added to the culture for $7 \mathrm{~d}$ or left with medium alone.

The adherent PBMCs was maintained in growth medium without cytokine to be remain as monocytes. To generate immature DCs (iDCs), the adherent cells were cultured in RPMI 1640, 10\% FBS, 400 U/mL GMCSF and $500 \mathrm{U} / \mathrm{mL}$ IL-4 for $14 \mathrm{~d}$. The differentiation into $\mathrm{mDCs}$ could be achieved by adding $1000 \mathrm{U} / \mathrm{mL}$ TNF- $\alpha$ (Amoytop Biotech, Xiamen, China) for $48 \mathrm{~h}$. The mDCs were incubated with AVS073 for $7 \mathrm{~d}$ either before or after maturation induction with TNF- $\alpha$ to generate pre-treated $\mathrm{mDCs}$ or treated $\mathrm{mDCs}$ respectively.

\section{Preparation of $\mathrm{CD}^{+} \mathrm{CD}^{+} 6^{+}$subsetof}

An aliquot of $10^{8}$ cells of day 14 CIK cells were harvested. $\mathrm{CD}^{+}{ }^{+} \mathrm{CD} 56^{+}$cells were isolated from CIK cells using CD3 microbead followed by CD56 Multisort Kit (Miltenyi Biotec, Germany) according to the manufacturer's instruction. The $\mathrm{CD}^{+} \mathrm{CD}^{+} 6^{+}$cell pellet was washed by adequate volume of the buffer, counted, and determined for viability by trypan blue exclusion. $\mathrm{CD}^{+} \mathrm{CD} 56^{+}$cells were resuspended in appropriated volume of growth medium (RPMI-1640, $10 \% \mathrm{FBS}$, and $300 \mathrm{IU} / \mathrm{mL}$ IL-2) to achieve a density of less than $1 \times 10^{6}$ cells $/ \mathrm{mL}$.

\section{Determination of cell proliferation}

(3-(4,5-dimethylthiazol-2-yl)-2,5-diphenyl) tetrazolium bromide was dissolved in the culture medium $(200 \mu \mathrm{g} / \mathrm{mL})$. The solution was added to each well. The plates were incubated at $37{ }^{\circ} \mathrm{C}$ in $5 \% \mathrm{CO}_{2}$ for $1 \mathrm{~h}$. After which time, the medium was discarded and $100 \mu \mathrm{L}$ of dimethyl sulfoxide was added. The plates were left at room temperature for $10 \mathrm{~min}$ with occasionally gently shaking. The absorbance in each well was measured at $595 \mathrm{~nm}$ and calculated as the percentage of the control as follows:

$$
\% \text { proliferation }=\frac{\mathrm{OD}(\text { sample })-\mathrm{OD}(\text { background })}{\mathrm{OD}(\text { control })-\mathrm{OD}(\text { background })} \times 100
$$

OD (sample) represents the OD of the well containing the treated cells. OD (control) represents the OD of the well containing untreated cells. OD (background) represents the OD of the blank well.

\section{Fluorescence-activated cell sorting (FACS) analysis}

PBLs were analyzed with fluorochrome-conjugated antibodies against CD3, CD8-, CD11a-, CD16-, CD28, CD56, CD69, CD152, CD154, CD278 (ICOS), CD279 (PD-1) (eBioscience, CA) and antibodies against regulatory $\mathrm{T}$ (Treg) cells (Biolegend). CIK phenotypes were analyzed with fluorochrome-conjugated antibodies against CD3, CD8, CD28, and CD56. DC phenotypes were analyzed with the following monoclonal markers: CD1a, CD11c, CD14, CD40, CD80, CD83, CD86 and HLA-DR (eBioscience). Cells were incubated with the corresponding fluorochrome-conjugated primary monoclonal antibodies at $4{ }^{\circ} \mathrm{C}$ for $30 \mathrm{~min}$ in the dark in $5 \mathrm{~mL}$ polystyrene round-bottom tube. The cells were washed by adding 2 $\mathrm{mL}$ of FACS buffer and pelleted by centrifugation at $400 \times$ $\mathrm{g}$ at $4{ }^{\circ} \mathrm{C}$ for $5 \mathrm{~min}$. The cells were resuspended in $200 \mu \mathrm{L}$ FACS buffer. Regulatory $\mathrm{T}$ (Treg) cells were detected in PBLs and CIK cells by Human Treg Flow ${ }^{\mathrm{TM}}$ kit included Foxp3 Alexa Fluor 488 and CD4 PE-Cy5/CD25 PE cocktail, according to the manufacturer's protocol. Flow cytometry analysis on 30,000 cells was performed using a FACSCalibur (Becton Dickinson, CA). Data were analyzed using FlowJo version 10.0.7.

RNA preparation and quantitative real-time PCR analysis After AVS073 treatment, DCs or $\mathrm{CD}^{+} \mathrm{CD}^{+} 6^{+}$cells were separately extracted for total mRNA by RNAspin mini RNA isolation kit (GE Healthcare, UK) according to the manufacturer's instruction. Total mRNA was converted to cDNA using Improm- $\mathrm{II}^{\mathrm{TM}}$ reverse transcription system (Promega, Madison, WI). The cDNA samples were tested 
for quality and quantity by NanoVue ${ }^{\text {tx }}$ Spectrophotometer (GE Healthcare, UK). The specific primers for DCs and $\mathrm{CD}^{+} \mathrm{CD} 6^{+}$cells (Table 1 ) were designed by Vector NTI version 10 and Primer Express 3.0 (Applied Biosystems, CA) and purchased from $1^{\text {st }}$ BASE (Singapore). The specific genes were amplified with Brilliant ${ }^{\circ}$ II SYBR ${ }^{\circ}$ Green QPCR master mix (Agilent Technologies, Waldbronn, Germany) in a StepOnePlus real-time PCR system (Applied Biosystems). Quantitative real-time PCR was performed using $300 \mathrm{ng}$ of cDNA in a $7.5 \mu \mathrm{L}$ of SYBR master mix containing $20 \mu \mathrm{M}$ primers and constituted to $15 \mu \mathrm{L}$ with water and amplified for 40 cycles of $95{ }^{\circ} \mathrm{C}$ for $15 \mathrm{~s}$, $56-60{ }^{\circ} \mathrm{C}$ for $40 \mathrm{~s}$, and $72{ }^{\circ} \mathrm{C}$ for $40 \mathrm{~s}$. The obtained Ct's were subtracted with the Ct of GAPDH of the same condition to obtain $\Delta \mathrm{Ct}$. The $\Delta \mathrm{Ct}$ 's of the treated cells were subtracted with $\Delta \mathrm{Ct}$ 's of the untreated cells of the same period to obtain $\Delta \Delta$ Ct's. The fold-changes could be obtained from the expression of $2^{-\Delta \Delta C t}$.

\section{Statistical analysis}

The results are shown as mean \pm standard error of the mean (SEM). Data were plotted and analyzed using GraphPad

Table 1 Primer pair and their information for quantitative real-time PCR

\begin{tabular}{|c|c|c|c|}
\hline Genes & Oligonucleotides $\left(5^{\prime} \rightarrow 3^{\prime}\right)$ & Size (bp) & Annealing $\left({ }^{\circ} \mathrm{C}\right)$ \\
\hline \multirow[t]{2}{*}{ GAPDH } & Forward: GAAATCCCATCACCATCTTCC & 124 & 60 \\
\hline & Reverse: AAATGAGCCCCAGCCTTCTC & & \\
\hline \multirow[t]{2}{*}{ IDO } & Forward: AGTCCGTGAGTTTGTCCTITCAA & 68 & 60 \\
\hline & Reverse: TTTCACACAGGCGTCATAAGCT & & \\
\hline \multirow[t]{2}{*}{ IFNY } & Forward: GTGTGGAGACCATCAAGGAAGAC & 80 & 60 \\
\hline & Reverse: CAGCTTTTCGAAGTCATCTCGTTT & & \\
\hline \multirow[t]{2}{*}{$\mid \mathrm{L}-4$} & Forward: AACAGCCTCACAGAGCAGAAGAC & 101 & 60 \\
\hline & Reverse: GCCCTGCAGAAGGTTTCCTT & & \\
\hline \multirow[t]{2}{*}{ IL-6 } & Forward: GCTGCAGGCACAGAACCA & 68 & 60 \\
\hline & Reverse: ACTCCTTAAAGCTGCGCAGAA & & \\
\hline \multirow[t]{2}{*}{ IL-10 } & Forward: CTGGGTTGCCAAGCCTTGT & 100 & 60 \\
\hline & Reverse: AGTTCACATGCGCCTTGATG & & \\
\hline \multirow[t]{2}{*}{ IL-12 } & Forward: GCAAAACCCTGACCATCCAA & 100 & 60 \\
\hline & Reverse: TGAAGCAGCAGGAGCGAAT & & \\
\hline \multirow[t]{2}{*}{$\mid \mathrm{L}-17$} & Forward: ACCTGTGTCACCCCGATTGT & 90 & 58 \\
\hline & Reverse: GGGTCGGCTCTCCATAGTCTAA & & \\
\hline \multirow[t]{2}{*}{ GATA3 } & Forward: ACTACGGAAACTCGGTCAGG & 100 & 60 \\
\hline & Reverse: CAGGGTAGGGATCCATGAAG & & \\
\hline \multirow[t]{2}{*}{ STAT1 } & Forward: GTGGCGGAACCCAGGAAT & 97 & 60 \\
\hline & Reverse: TGACAGAAGAAAACTGCCAACTCA & & \\
\hline \multirow[t]{2}{*}{ STAT3 } & Forward: ACCAAGCGAGGACTGAGCAT & 90 & 58 \\
\hline & Reverse: TGTGATCTGACACCCTGAATAATTC & & \\
\hline \multirow[t]{2}{*}{ STAT4 } & Forward: TTCCTTCTGTTITATCCCCATCT & 128 & 60 \\
\hline & Reverse: TGTTGTGGGACTCAGGTTTTCTC & & \\
\hline \multirow[t]{2}{*}{ STAT5A } & Forward: CACGCAGGACACAGAGAATGA & 80 & 58 \\
\hline & Reverse: TCAGGCTCTCCTGGTACTGGAT & & \\
\hline \multirow[t]{2}{*}{ STAT5B } & Forward: GGTCACGCAGGACACAGAGAA & 110 & 58 \\
\hline & Reverse: CCAGCGGGCCAAACTG & & \\
\hline \multirow[t]{2}{*}{ STAT6 } & Forward: CTITTGGCAGTGGTTTGATGGT & 96 & 60 \\
\hline & Reverse: TGTTTGCTGATGAAGCCAATG & & \\
\hline \multirow[t]{2}{*}{ T-bet } & Forward: AGGATTCCGGGAGAACTTTGA & 123 & 60 \\
\hline & Reverse: TACTGGTTGGGTAGGAGAGGAGAGTA & & \\
\hline \multirow[t]{2}{*}{ RORC } & Forward: CCACAGAGACATCACCGAGCC & 114 & 60 \\
\hline & Reverse: GTGGATCCCAGATGACTTGTCC & & \\
\hline
\end{tabular}


Prism Software version 5.03. Student's $t$-test was used for flow cytometry and real-time PCR analysis. One-way ANOVA with Dunnett's test was used to determine the significance of difference between the controls and treatments. Two-way ANOVA with Bonferoni test was used to analyze statistical significance of the difference between means of cytotoxic experiments. A $p$-value $<0.05$ was considered significant.

\section{Results}

The effects of AVS073 on the viability and proliferation of monocytes, PBLs and CIK cells

AVS073 (1 ng/mL-3,000 $\mu \mathrm{g} / \mathrm{mL})$ were incubated with PBLs and CIK cells for $3 \mathrm{~d}$ and determined for cell viability by trypan blue exclusion assay. The relatively low doses of AVS073 (1 ng/mL-30 $\mu \mathrm{g} / \mathrm{mL})$ did not harm the cultured cells. At higher doses (100-3,000 $\mu \mathrm{g} / \mathrm{mL})$, AVS073 compromised the viability of these cells (Fig. 1a). A range of $1-100 \mu \mathrm{g} / \mathrm{mL}$ AVS073 was brought to proliferation assay using MTT. The proliferation of these cells was highly improved after being cultured with $30-100 \mu \mathrm{g} / \mathrm{mL}$ of AVS073 (Fig. 1b). The viability of cultured cells after $3 \mathrm{~d}$ was not compromised until the concentration reached $100 \mu \mathrm{g} / \mathrm{mL}$. AVS073 at $30 \mu \mathrm{g} / \mathrm{mL}$ was selected for subsequent phenotypic and functional assays after being incubated with the selected immune cells for $7 \mathrm{~d}$. The selected concentration did not compromise the $\mathrm{mDCs}$ ' viability (>90\% viability) nor induce any alteration to cellular morphology and markers throughout the study (data not shown).
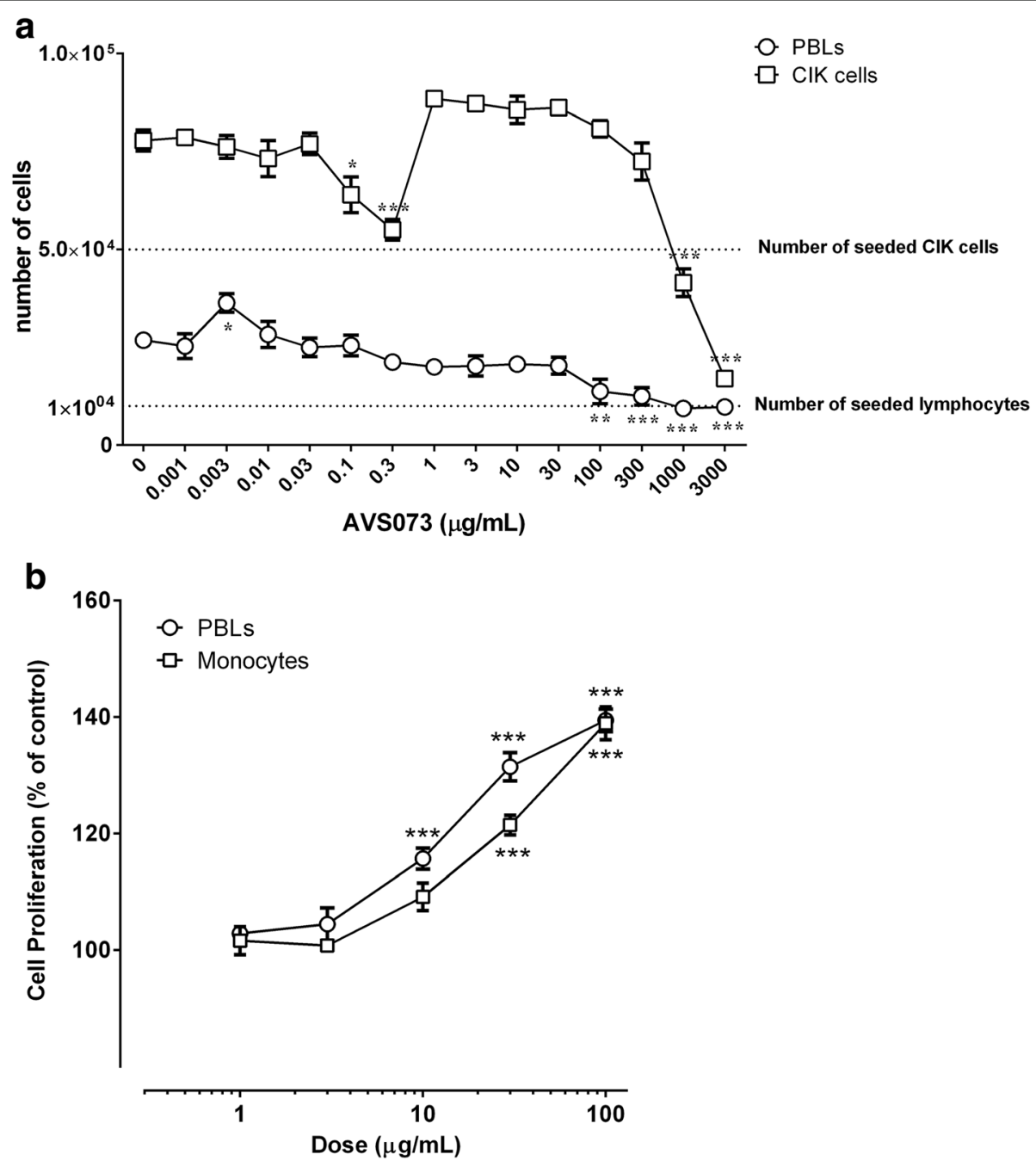

Fig. 1 The concentration-toxicity relationship of AVSO73 toward immune cells was evaluated using trypan blue assay and MTT assay to obtain suitable studying concentrations. The viability of PBLs (O) and CIK cells ( $\square$ ) after being exposed to AVSO73 for $3 \mathrm{~d}$ was determined by trypan blue exclusion assay (a). Data are represented as mean \pm SEM $(n=6)$. The MTT assay $(\mathbf{b})$ demonstrated the proliferative effects of AVSO73 on PBLs (o) and monocytes ( $\square$ ) after $7 \mathrm{~d}$-culture. Data are represented as mean $\pm \operatorname{SEM}(n=8) .{ }^{*}$, ** and ${ }^{* * *}$ represent data with statistically significant difference from those of the untreated cells with $p<0.05, p<0.01$ and $<0.001$ respectively 
The phenotypic characterization and the proportions of $\mathrm{CD}^{+} \mathrm{CD}_{56}{ }^{+}$and Treg subsets in PBLs and in CIK cells

There were no significantly alteration in the activation and differentiation markers (Fig. 2): including lymphocyte early activation marker (CD69), adhesion molecule (CD11a), cositmulatory molecules (CD8, CD28, CD154 and CD278), co-inhibitory molecule (CD152; CTLA-4) and negative regulatory molecule (CD279; PD1), NK cell markers (CD16, CD56) and T cell markers (CD3, CD4, CD8, CD25, Foxp3) in PBLs after being treated with AVS073. Regarding the subset proportions, either PBLs (Fig. 3a) or CIK cells (Fig. 3b) were exposed to AVS073 for $7 \mathrm{~d}$. There was no significant alteration in the proportions of $\mathrm{CD}^{+} \mathrm{CD}^{+} 6^{+}, \mathrm{CD}^{+} \mathrm{CD}^{-} 6^{-}, \mathrm{CD}^{-} \mathrm{CD} 56^{+}$, nor Treg subsets within both PBLs and CIK cells after AVS073 treatment.

The analysis for the polarization of $\mathrm{CD}^{+}{ }^{+} \mathrm{CD} 56^{+}$cells after the exposure to AVS073

The isolated $\mathrm{CD}^{+}{ }^{+} \mathrm{CD} 56^{+}$subset incubated with $30 \mu \mathrm{g} / \mathrm{mL}$ of AVS073 for $7 \mathrm{~d}$ were extracted for total mRNA and analyzed for the polarization markers. For Th1 markers, the expression of STAT4, T-bet, and IFN- $\gamma$, but not STAT1, were significantly increased (Fig. 4a). For Th2 markers, STAT6 expression was significantly decreased, but neither was GATA3 nor IL-4 (Fig. 4b). For Treg markers, STAT5A, STAT5B and IDO were significantly decreased, but neither was IL-10 (Fig. 4c). For Th17 markers, STAT3, RORC and IL-17 were increased (Fig. 4d).

\section{The phenotypic characterization of DCs after AVS073} treatment

The expression of CD40, CD80, CD83 and CD86 were not altered in mDCs treated with AVS073 regardless of the treatment timing (Fig. 5). The expression of HLA-DR was not significantly altered in DCs regardless of the timing of AVS073 treatment. The expression of CD14, a monocyte marker, was suppressed in mDCs treated with AVS073.

\section{The alteration to the cytokines in mDCs after the exposure to AVS073}

The level of IL-12, a Th1-prone cytokine, was rising in AVS073-treated mDCs (Fig. 6). AVS073 significantly increased the level of Th17-prone cytokines, IL-6 and IL-23 in AVS073-treated mDCs. The level of IL-10, an immunosuppressive cytokine that promote Treg development, was not altered.

\section{Discussion}

The phenotypic changes to PBLs

AVS073 did not alter the phenotypic characterization of PBLs: T-cell markers (CD3, CD4 and CD8), NKcell markers (CD16 and CD56), activation markers (CD25, CD69), co-stimulatory molecules (CD28, CD40L, and ICOS), co-inhibitory molecule (CD152 or CTLA-4) or negative regulatory molecule (CD279 or PD-1). Moreover, AVS073 did not alter the proportion of Treg cells subset.

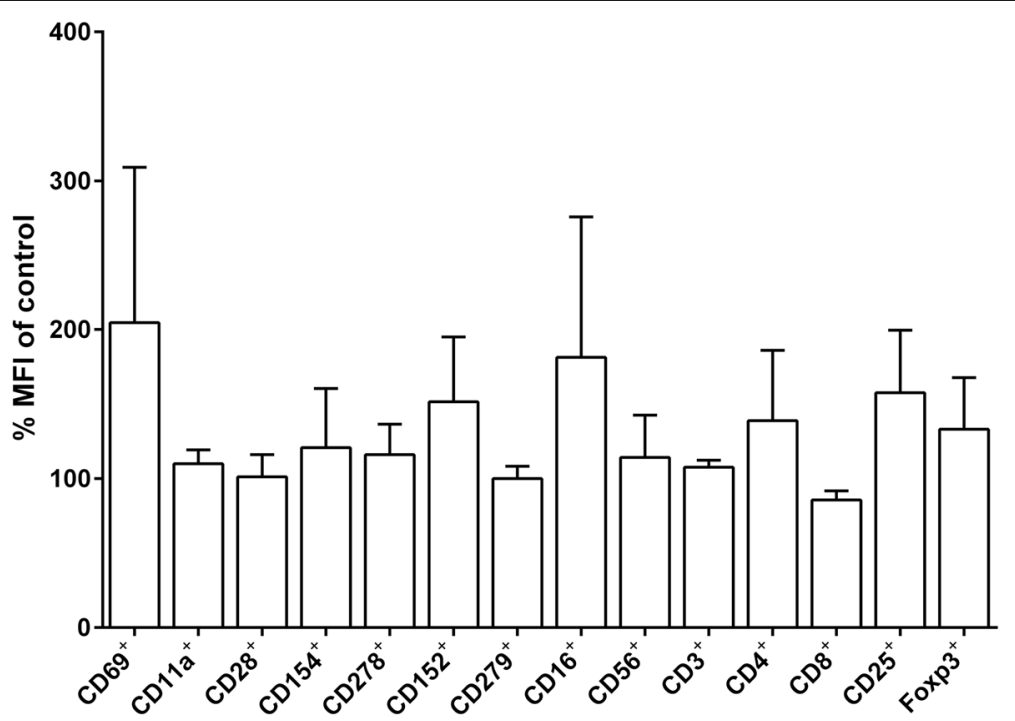

Fig. 2 AVS073 was investigated for its potential action toward lymphocyte activation and differentiation in PBLs. The corresponding cellular markers were investigated using FACS. The mean fluorescence intensity (MFI) of lymphocyte markers was taken from FACS analysis of PBLs after the exposure to $30 \mu \mathrm{g} / \mathrm{mL}$ AVSO73 for $7 \mathrm{~d}$. Data are represented as mean \pm SEM $(n=3)$ of $\%$ of untreated control. The unpaired $t$-test was used to analyze the statistically significant by compared with $100 \%$ control at $p<0.05$ 

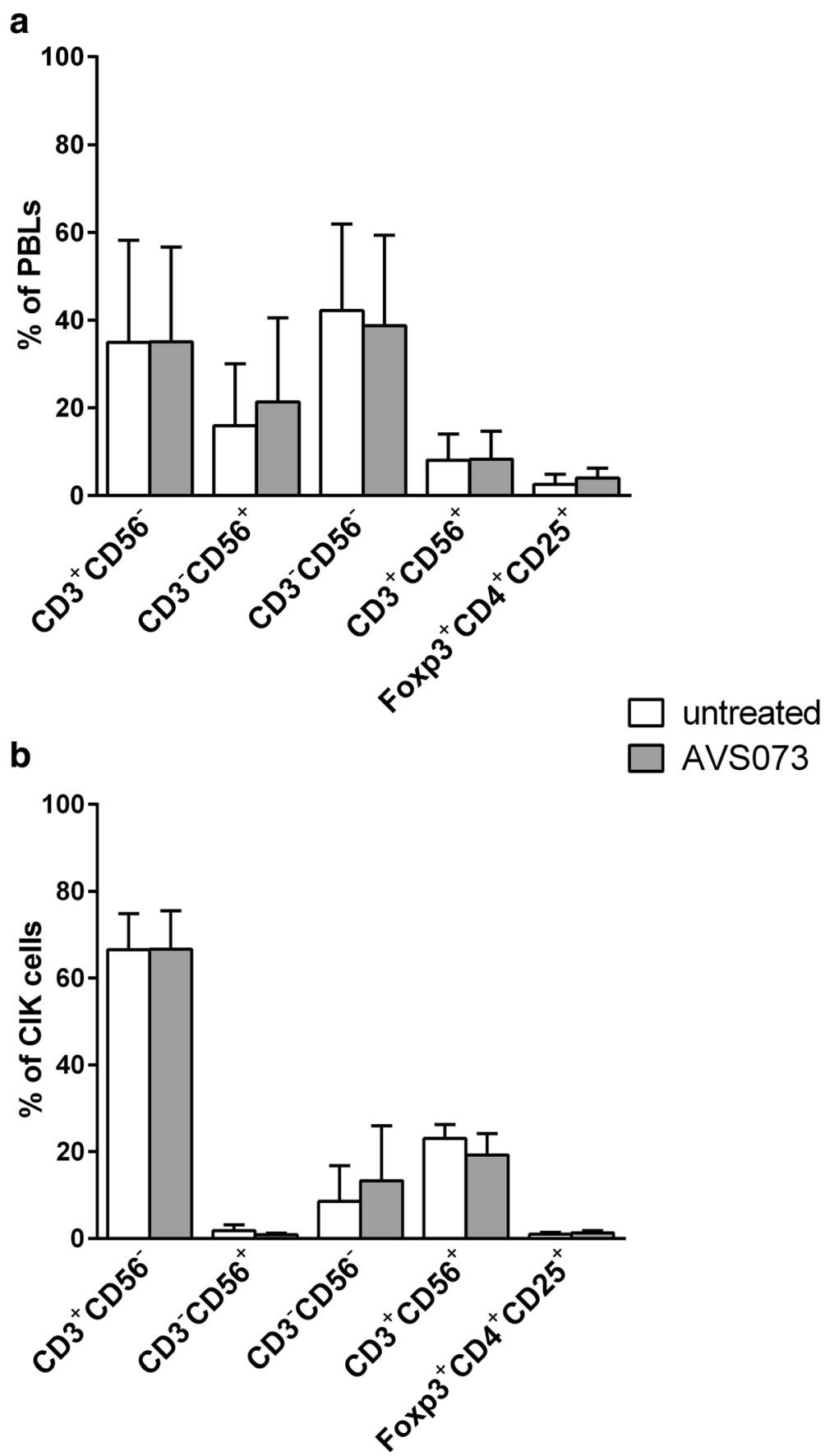

Fig. 3 AVS073 was investigated for its potential action on the proportion of subsets in PBLs and CIK cells. The alteration in the proportions of $\mathrm{CD}^{+} \mathrm{CD}_{56}, \mathrm{CD}^{-} \mathrm{CD}_{56}{ }^{+}, \mathrm{CD}^{+} \mathrm{CD}^{+} 6^{+}$and Treg subsets was evaluated in PBLs (a) and CIK cells (b) after AVS073 exposure. Cells were cultured in presence or absence of $30 \mu \mathrm{g} / \mathrm{mL}$ AVS073 for $7 \mathrm{~d}$. Data are presented as mean \pm SEM $(n=3)$. The paired $t$-test was used to analyze the statistically significant at $p<0.05$

The alteration to the CIK cell subsets

The absolute number of $\mathrm{CD}^{+} \mathrm{CD}^{+} 6^{+}$subset at 21 -d CIK cell increased up to 10 folds over that in the initial PBLs. AVS073 had not altered the proportion of $\mathrm{CD}^{+} \mathrm{CD}^{+} 6^{+}$ nor other subsets in both PBLs and CIK cells. The CD3 ${ }^{+} \mathrm{CD}_{56}{ }^{+}$subset was isolated from the CIK cells to monitor the alteration in Th1/Th2/Th17/Treg phenotypes after AVS073 treatment. The AVS073-treated CD3 ${ }^{+} \mathrm{CD} 56{ }^{+}$subset expressed more STAT4, that indicated the polarization toward Th1 phenotype. The Th2 and Treg phenotypes in AVS073-treated $\mathrm{CD}^{+} \mathrm{CD} 6^{+}$subset was suppressed as evidenced by the decrease in STAT6 
a

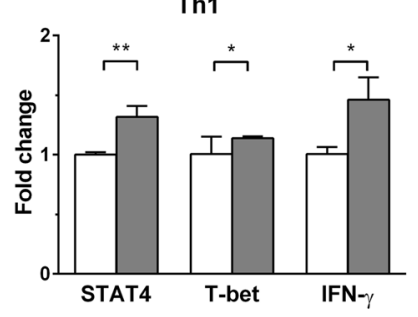

C

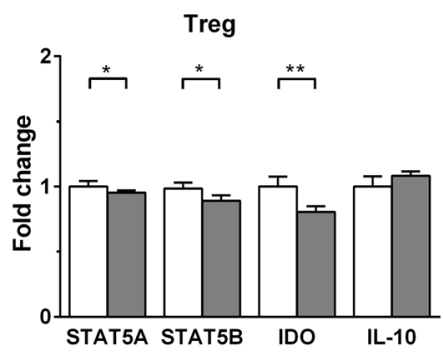

b

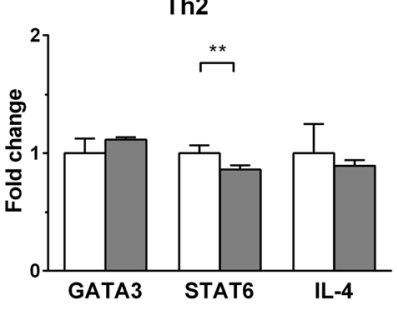

d $\square \mathrm{CD}^{+} \mathrm{CD}^{+} 6^{+}$cells

Th17 $\square$ AVS073-CD $3^{+}$CD $56^{+}$cells

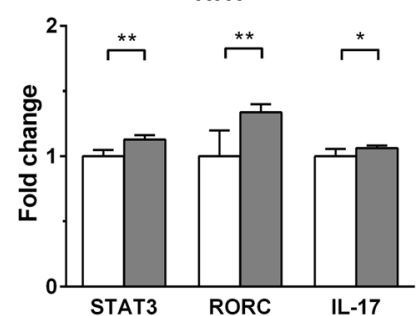

Fig. 4 AVS073 was investigated for its potential actions toward the expression of polarization markers in $C D 3^{+}$CD56 ${ }^{+}$cells. The expression data of cytokines and transcription factors in $\mathrm{CD}^{+}{ }^{+} \mathrm{CD} 56^{+}$subset after the exposure to $30 \mu \mathrm{g} / \mathrm{mL}$ AVSO73 for $7 \mathrm{~d}$ were evaluated using quantitative real-time PCR analysis. Data are represented as mean \pm SEM $(n=4){ }^{*}$ and ${ }^{* *}$ represent data with statistically significant difference from those of the untreated cells with $p<0.05$ and $p<0.01$ respectively

and STAT5A expressions, respectively. The Th17 phenotype was enhanced after AVS073 treatment as evidenced by increasing STAT3, RORC and IL-17 expression. Therefore, AVS073 tended to promote the Th1 and Th17 phenotypes in the $\mathrm{CD}^{+}{ }^{+} \mathrm{CD} 56^{+}$subset at the expense of Th2 and Treg phenotypes. The promotion of Th1 and Th17 phenotypes by the AVS073-treated $\mathrm{CD}^{+} \mathrm{CD} 56^{+}$ subset would make this preparation a candidate for anti-cancer treatment. Th17 cells exhibited pivotal roles in anti-tumor activity depending on the cytokines, costimulatory molecules and cell-cell interactions in the tumor microenvironment. The presence of IFN- $\gamma$ together with IL-17 would promote tumor regression [53].

\section{Phenotype and maturation of DCs}

The phenotypic changes induced by AVS073 might be attributed by its components. The Carthamus tinctorius L., one of AVS073's components, was reported to promote the expression of maturation markers (CD80, MHC class I and II) in mouse bone-marrow-derived

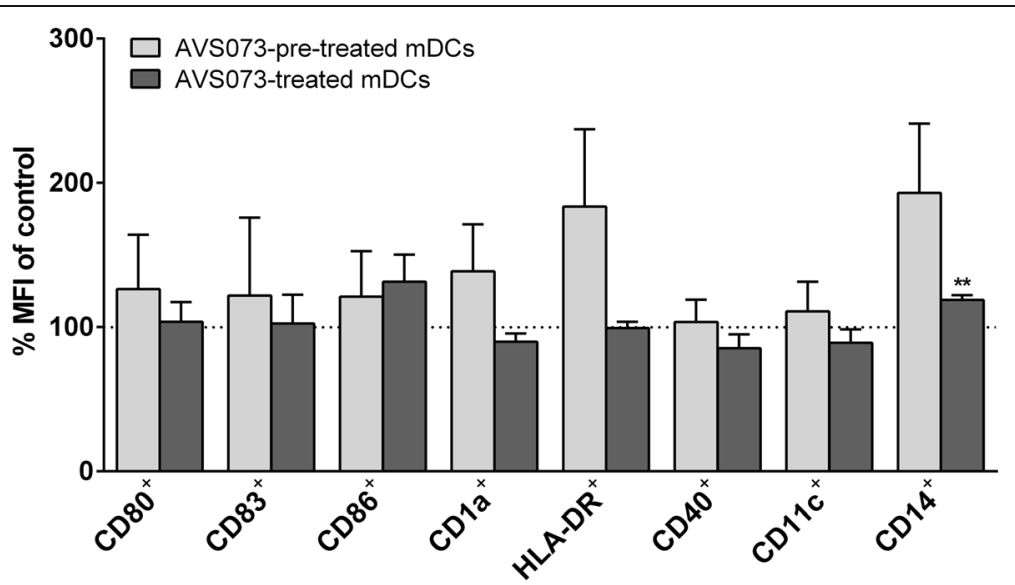

Fig. 5 AVS073 was investigated for its potential action on the differentiation of mDCs. The MFI of differentiation markers on DCs after the exposure to $30 \mathrm{\mu g} / \mathrm{mL}$ AVSO73 for $7 \mathrm{~d}$ were determined using FACS analysis. Data are represented as mean fluorescence intensity (\% of the respective controls) \pm SEM $(n=3)$. AVS073-pre-treated mDCs refers to DCs that exposed to AVS073 prior to TNF-a induced maturation. AVS073-treated mDCs refers to mDCs exposed to AVS073 after TNF-a induced maturation. The controls for AVS073-pre-treated-mDCs and AVS073-treated-mDCs were the untreated $\mathrm{mDCs}$. * represents data with statistically significant difference from $100 \%$ control with $p<0.05$ 


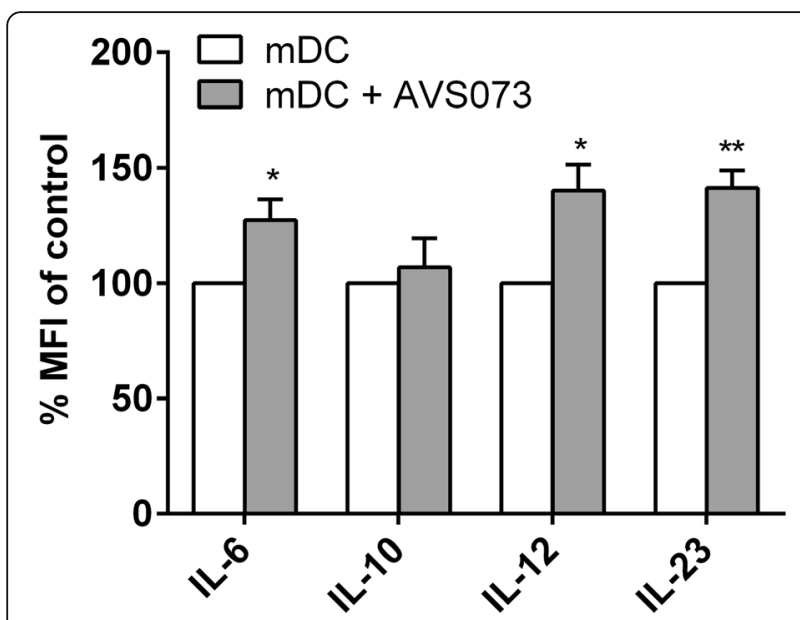

Fig. 6 AVS073 was evaluated for its action on the polarization of mDCs. Flow cytometry analysis was used to evaluate the alteration of Th1/Th2/Th17 cytokines in mDCs after the exposure to $30 \mu \mathrm{g} / \mathrm{mL}$ AVS073 for $7 \mathrm{~d}$. Data are represented as MFI (\% of the respective controls) \pm SEM $(n=6)$. The controls for AVS073-treated mDCs were the untreated $\mathrm{mDCs}$. ${ }^{*}$ and ${ }^{* *}$ represent data with statistically significant difference from those of the untreated cells with $p<0.05$ and $p<0.01$ respectively

DCs and maintained the high profile of maturation markers (CD80, CD86, MHC class I and II) in tumor antigen pulsed-DCs [31]. In contrast, Piper nigrum Linn. extract, piperine, significantly inhibited the maturation (MHC class II, CD40 and CD86), cytokine production (TNF- $\alpha$ and IL-12), phosphorylation of ERK and JNK, but enhanced the endocytosis activity of LPS-induced bone-marrow-derived DCs [32]. However, we did not observe significant alteration in the maturation markers of both conditions of treated mDCs.

\section{Alteration to Th-polarizing profiles in DCs}

The AVS073-treated mDCs carried more IL-12, the Th1-prone cytokine. AVS073 did not alter the IL-10 level, and therefore did not shift mDCs toward Tregpromoting activity. The cytokine levels of both IL-6 and IL-23 in AVS073-treated mDCs were increased, and therefore induced the Th17 polarization. IL-6 and TGF$\beta$ are necessary for the initial induction of Th17 differentiation whereas IL-23 is essential for the later stage of Th17 polarization [54]. IL-6 activates, while together with IL-21 further sustains STAT3 signaling required for ROR- $\alpha$ expression, and restrain Foxp 3 mediated repression of ROR- $\alpha$. TGF- $\beta$ induces ROR- $\alpha$ expression through SMAD phosphorylation and provokes IL-23 receptor expression in naïe $\mathrm{T}$ cells, rendering them receptive to IL-23. IL-23 cements Th17 lineage commitment such that Th17 cells induced with TGF- $\beta 1$ and IL-6 are insufficiently committed to the lineage and therefore plays a vital role in promoting Th17-mediated tissue inflammation [55].
The alteration to Th profiles would affect, in particular, immunocompromised patients. The Th1 and Th17 enhancing effects of AVS073 may boost protective adaptive immunity against infection and cancer while Th2-supppressing activity may also provide clinical benefit in allergic diseases including asthma. However, all mentioned have to be optimized with its effect on Treg suppression to prevent overt immune reaction. The pathogenesis of tumor immune evasion relies on immunosuppressive cells (e.g., Tregs) to establish an immunosuppressive tumor microenvironment. If this is the case, AVS073 can inhibit Tregs, and therefore attenuate tumor immune evasion and dampen cancer progression. Similarly, the pathogenesis of Th2-associated asthma is perpetuated by Th2 cytokine microenvironment that may be suppressed by AVS073 through downregulation of Th2 cells. However, we further need to study how to direct AVS073-treated CIK cells towards decisive immune boosting for reversing each disease condition as mentioned.

\section{Conclusions}

The present study has demonstrated the effect of AVS073 on CIK and mDCs directing immune axis towards prominent Th1 and Th17 response while suppressing Th2 and Treg polarization. This molecular mechanism may provide clinical implication not only in boosting host protective immunity against infection and tumor immune evasion, but also reversing immune deviation in allergic diseases.

\section{Additional file}

Additional file 1: The identity of mDCs was demonstrated using flow cytometry analysis for DC markers. The studied markers included CD80, CD83, CD86, CD40 and HLA-DR. (TIF 1013.76 kb)

\section{Abbreviations}

AVS073: Ayurved Siriraj Wattana recipe; CIK: Cytokine-induced killer: DCs: Dendritic cells; FACS: Fluorescence-activated cell sorting; mDCs: Mature DCs; PBLs: Peripheral blood lymphocytes; PBMCs: Peripheral blood mononuclear cells; Treg: Regulatory T cell

\section{Acknowledgements}

AW, PA, TL and KM are recipients of Chalermphrakiat Grant of the Faculty of Medicine Siriraj Hospital, Mahidol University.

\section{Funding}

The work was supported by the Grant for Goal-oriented Research Project of Mahidol University and the Thailand Research Fund (TRF) awarded to AW.

\section{Availability of data and materials}

The datasets supporting the conclusions of this article are included within the article.

\section{Authors' contributions}

AW served as the principal investigator. AW and NN contributed to the study design. NN, WW, KK and SD carried out the experiments, collected and statistically analyzed data. AW, NN and KM interpreted data, drafted manuscript. AW, KM, KS, PA and TL revised manuscript. All authors read and approved the final version of manuscript. 


\section{Competing interests}

The authors declare that they have no competing interests. The funders had no involvement in study design; in the collection, analysis and interpretation of data; in the writing of the report; and in the decision to submit the article for publication.

\section{Consent for publication}

Not applicable.

\section{Ethics approval and consent to participate}

The protocol was approved by the Institutional Review Board of the Faculty of Medicine Siriraj Hospital, Mahidol University, Bangkok, Thailand with the protocol number 258/2556(EC1).

\section{Author details}

'Department of Pharmacology, Faculty of Medicine Siriraj Hospital, Mahidol University, Bangkok 10700, Thailand. ${ }^{2}$ Center of Applied Thai Traditional Medicine, Faculty of Medicine Siriraj Hospital, Mahidol University, Bangkok 10700, Thailand. ${ }^{3}$ Department of Medicine, Faculty of Medicine Siriraj Hospital, Mahidol University, 2 Wanglang Road, Bangkoknoi, Bangkok 10700, Thailand. ${ }^{4}$ Department of Biochemistry, Faculty of Pharmacy, Mahidol University, Bangkok 10400, Thailand.

Received: 14 July 2016 Accepted: 10 November 2016

\section{Published online: 29 November 2016}

\section{References}

1. Panich U, Pluemsamran T, Tangsupa-a-nan V, Wattanarangsan J, Phadungrakwittaya R, Akarasereenont P, et al. Protective effect of AVS073, a polyherbal formula, against UVA-induced melanogenesis through a redox mechanism involving glutathione-related antioxidant defense. BMC Complement Altern Med. 2013;13:159.

2. Bunnan K, Chaikomin R, Lohsiriwat S, Chomchai S, Akarasereenont P. Effect of Ayuraved Siriraj herbal recipe "Wattana" on gastric emptying rate. Siriraj Med J. 2012;64:89-93.

3. Duangsa-ard S, Wongkajornsilp A, Akarasereenont P, Huabprasert S, Chongputtharaksa T, Laohapand T. The effects of Ayurved Siriraj Wattana recipe on splenocytes in Wistar rat. Siriraj Med J. 2013;65:73-6.

4. Pengkhum T, Chatsiricharoenkul S, Akarasereenont P, Charoencholvanich K. Phase II clinical trial of Ayurved Siriraj Wattana Recipe for symptomatic relief in patients with osteoarthritis of the knee. J Med Assoc Thai. 2012;95(3):452-60.

5. Baliga MS, Bhat HP, Joseph N, Fazal F. Phytochemistry and medicinal uses of the bael fruit (Aegle marmelos Correa): A concise review. Food Res Int. 2011;44(7):1768-75.

6. Sharma CK, Sharma M, Sharma V. Therapeutic Potential of the Medicinal Plant Aegle Marmelos (Linn.) Correa: Insight. J Environ Pathol Toxicol Oncol. 2016;35(1):1-10.

7. Morikawa T, Funakoshi K, Ninomiya K, Yasuda D, Miyagawa K, Matsuda H, et al. Medicinal foodstuffs. XXXIV. Structures of new prenylchalcones and prenylflavanones with TNF-alpha and aminopeptidase N inhibitory activities from Boesenbergia rotunda. Chem Pharm Bull (Tokyo). 2008;56(7):956-62.

8. Ng KB, Bustamam A, Sukari MA, Abdelwahab SI, Mohan S, Buckle MJ, et al. Induction of selective cytotoxicity and apoptosis in human T4lymphoblastoid cell line (CEMss) by boesenbergin a isolated from boesenbergia rotunda rhizomes involves mitochondrial pathway, activation of caspase 3 and G2/M phase cell cycle arrest. BMC Complement Altern Med. 2013;13:41.

9. Isa NM, Abdelwahab SI, Mohan S, Abdul AB, Sukari MA, Taha MM, et al. In vitro anti-inflammatory, cytotoxic and antioxidant activities of boesenbergin A, a chalcone isolated from Boesenbergia rotunda (L.) (fingerroot). Braz J Med Biol Res. 2012;45(6):524-30.

10. Wang YZ, Sun SQ, Zhou YB. Extract of the dried heartwood of Caesalpinia sappan L. attenuates collagen-induced arthritis. J Ethnopharmacol. 2011; 136(1):271-8.

11. Nirmal NP, Rajput MS, Prasad RG, Ahmad M. Brazilin from Caesalpinia sappan heartwood and its pharmacological activities: A review. Asian Pac J Trop Med. 2015;8(6):421-30.

12. Mueller M, Weinmann $D$, Toegel S, Holzer W, Unger FM, Viernstein $H$. Compounds from Caesalpinia sappan with anti-inflammatory properties in macrophages and chondrocytes. Food Funct. 2016;7(3):1671-9.
13. Tewtrakul S, Tungcharoen P, Sudsai T, Karalai C, Ponglimanont C, Yodsaoue O. Antiinflammatory and Wound Healing Effects of Caesalpinia sappan L. Phytother Res. 2015;29(6):850-6.

14. Zhou X, Tang L, Xu Y, Zhou G, Wang Z. Towards a better understanding of medicinal uses of Carthamus tinctorius $L$. in traditional Chinese medicine: a phytochemical and pharmacological review. J Ethnopharmacol. 2014;151(1):27-43.

15. Kuehnl S, Schroecksnadel S, Temml V, Gostner JM, Schennach H, Schuster D, et al. Lignans from Carthamus tinctorius suppress tryptophan breakdown via indoleamine 2,3-dioxygenase. Phytomedicine. 2013;20(13):1190-5.

16. Yao D, Wang Z, Miao L, Wang L. Effects of extracts and isolated compounds from safflower on some index of promoting blood circulation and regulating menstruation. J Ethnopharmacol. 2016;191:264-72.

17. Laupattarakasem P, Wangsrimongkol T, Surarit R, Hahnvajanawong C. In vitro and in vivo anti-inflammatory potential of Cryptolepis buchanani. J Ethnopharmacol. 2006;108(3):349-54.

18. Laupattarakasem P, Houghton PJ, Hoult JR, Itharat A. An evaluation of the activity related to inflammation of four plants used in Thailand to treat arthritis. J Ethnopharmacol. 2003;85(2-3):207-15.

19. Hanprasertpong N, Teekachunhatean S, Chaiwongsa R, Ongchai $S$, Kunanusorn P, Sangdee C, et al. Analgesic, anti-inflammatory, and chondroprotective activities of Cryptolepis buchanani extract: in vitro and in vivo studies. Biomed Res Int. 2014;2014:978582.

20. Zhou ZL, Yin WQ, Yang YM, He CH, Li XN, Zhou CP, et al. New Iridoid Glycosides with Antidepressant Activity Isolated from Cyperus rotundus. Chem Pharm Bull (Tokyo). 2016;64(1):73-7.

21. Nam JH, Nam DY, Lee DU. Valencene from the Rhizomes of Cyperus rotundus Inhibits Skin Photoaging-Related Ion Channels and UV-Induced Melanogenesis in B16F10 Melanoma Cells. J Nat Prod. 2016;79(4):1091-6.

22. Ahmad W, Jantan I, Kumolosasi E, Bukhari SN. Immunostimulatory effects of the standardized extract of Tinospora crispa on innate immune responses in Wistar Kyoto rats. Drug Des Devel Ther. 2015;9:2961-73.

23. Abood WN, Fahmi I, Abdulla MA, Ismail S. Immunomodulatory effect of an isolated fraction from Tinospora crispa on intracellular expression of INF-gamma, IL-6 and IL-8. BMC Complement Altern Med. 2014;14:205.

24. Znati M, Ben Jannet $\mathrm{H}$, Cazaux S, Souchard JP, Harzallah Skhiri F, Bouajila J. Antioxidant, 5-lipoxygenase inhibitory and cytotoxic activities of compounds isolated from the Ferula lutea flowers. Molecules (Basel, Switzerland). 2014;19(10):16959-75.

25. Hasan MM, Uddin N, Hasan MR, Islam AF, Hossain MM, Rahman AB, et al. Analgesic and anti-inflammatory activities of leaf extract of Mallotus repandus (Willd.) Muell. Arg Biomed Res Int. 2014;2014:539807.

26. Kumar CU, Pokuri VK, Pingali U. Evaluation of the Analgesic Activity of Standardized Aqueous Extract of Terminalia chebula in Healthy Human Participants Using Hot Air Pain Model. J Clin Diagn Res. 2015;9(5):FC01-4.

27. Puttarak P, Sawangjit R, Chaiyakunapruk N. Efficacy and safety of Derris scandens (Roxb.) Benth. for musculoskeletal pain treatment: A systematic review and meta-analysis of randomized controlled trials. J Ethnopharmacol. 2016;194:316-323.

28. Bagheri SM, Hedesh ST, Mirjalili A, Dashti RM. Evaluation of Antiinflammatory and Some Possible Mechanisms of Antinociceptive Effect of Ferula assa foetida Oleo Gum Resin. J Evid Based Complementary Altern Med. 2016;21(4):271-6.

29. Eshwarappa RS, Ramachandra YL, Subaramaihha SR, Subbaiah SG, Austin RS, Dhananjaya BL. Anti-Lipoxygenase Activity of Leaf Gall Extracts of Terminalia chebula (Gaertn.) Retz. (Combretaceae). Pharmacognosy Res. 2016;8(1):78-82

30. Kalaiselvan S, Rasool MK. The anti-inflammatory effect of triphala in arthriticinduced rats. Pharm Biol. 2015;53(1):51-60.

31. Chang JM, Hung LM, Chyan YJ, Cheng CM, Wu RY. Carthamus tinctorius Enhances the Antitumor Activity of Dendritic Cell Vaccines via Polarization toward Th1 Cytokines and Increase of Cytotoxic T Lymphocytes. Evid Based Complement Alternat Med. 2011;2011:274858.

32. Bae GS, Kim JJ, Park KC, Koo BS, Jo IJ, Choi SB, et al. Piperine inhibits lipopolysaccharide-induced maturation of bone-marrow-derived dendritic cells through inhibition of ERK and JNK activation. Phytother Res. 2012; 26(12):1893-7.

33. Choi YK, Cho SG, Woo SM, Yun YJ, Jo J, Kim W, et al. Saussurea lappa Clarke-Derived Costunolide Prevents TNF alpha -Induced Breast Cancer Cell Migration and Invasion by Inhibiting NF- kappa B Activity. Evid Based Complement Alternat Med. 2013;2013:936257. 
34. Baskar AA, Al Numair KS, Alsaif MA, Ignacimuthu S. In vitro antioxidant and antiproliferative potential of medicinal plants used in traditional Indian medicine to treat cancer. Redox Rep. 2012;17(4):145-56.

35. George SK, Radhakrishnan R, Kumar SS, Sreelekha T, Balaram P. Chemopreventive efficacy of Aegle marmelos on murine transplantable tumors. Integr Cancer Ther. 2014;13(1):68-78.

36. Sangmalee S, Laorpaksa A, Sritularak B, Sukrong S. Bioassay-Guided Isolation of Two Flavonoids from Derris scandens with Topoisomerase II Poison Activity. Biol Pharm Bull. 2016;39(4):631-5.

37. Do MT, Kim HG, Choi JH, Khanal T, Park BH, Tran TP, et al. Antitumor efficacy of piperine in the treatment of human HER2-overexpressing breast cancer cells. Food Chem. 2013;141(3):2591-9.

38. Zhang $X$, Lin D, Jiang R, Li H, Wan J, Li H. Ferulic acid exerts antitumor activity and inhibits metastasis in breast cancer cells by regulating epithelial to mesenchymal transition. Oncol Rep. 2016:36(1):271-8.

39. Lin X, Peng Z, Su C. Potential anti-cancer activities and mechanisms of costunolide and dehydrocostuslactone. Int J Mol Sci. 2015;16(5):10888-906.

40. Ravi Shankara BE, Ramachandra YL, Rajan SS, Ganapathy PS, Yarla NS, Richard SA, et al. Evaluating the Anticancer Potential of Ethanolic Gall Extract of Terminalia chebula (Gaertn.) Retz. (Combretaceae). Pharmacognosy Res. 2016;8(3):209-12.

41. Afzali B, Lombardi G, Lechler RI, Lord GM. The role of T helper 17 (Th17) and regulatory $T$ cells (Treg) in human organ transplantation and autoimmune disease. Clin Exp Immunol. 2007;148(1):32-46.

42. Lee Y, Awasthi A, Yosef N, Quintana FJ, Xiao S, Peters A, et al. Induction and molecular signature of pathogenic TH17 cells. Nat Immunol. 2012;13(10):991-9.

43. Kimura A, Kishimoto T. IL-6: regulator of Treg/Th17 balance. Eur J Immunol. 2010;40(7):1830-5.

44. Zhou P, Liang P, Dong B, Yu X, Han Z, Xu Y. Phase clinical study of combination therapy with microwave ablation and cellular immunotherapy in hepatocellular carcinoma. Cancer Biol Ther. 2011;11(5):450-6.

45. Munn DH. Indoleamine 2,3-dioxygenase, Tregs and cancer. Curr Med Chem. 2011:18(15):2240-6.

46. Ankathatti Munegowda M, Deng Y, Mulligan SJ, Xiang J. Th17 and Th17stimulated CD8(+) T cells play a distinct role in Th17-induced preventive and therapeutic antitumor immunity. Cancer Immunol Immunother. 2011; 60(10):1473-84

47. Yang M, Ma C, Liu S, Sun J, Shao Q, Gao W, et al. Hypoxia skews dendritic cells to a Thelper type 2-stimulating phenotype and promotes tumour cell migration by dendritic cell-derived osteopontin. Immunology. 2009;128(1 Suppl):e237-49.

48. Vichchatorn P, Wongkajornsilp A, Petvises S, Tangpradabkul S, Pakakasama S, Hongeng S. Dendritic cells pulsed with total tumor RNA for activation NK-like T cells against glioblastoma multiforme. J Neuro-Oncol. 2005;75(2):111-8.

49. Wongkajornsilp A, Wamanuttajinda V, Kasetsinsombat K, Duangsa-ard S, Sa-ngiamsuntorn K, Hongeng $S$, et al. Sunitinib indirectly enhanced anti-tumor cytotoxicity of cytokine-induced killer cells and CD3(+)CD56(+) subset through the co-culturing dendritic cells. PLoS One. 2013;8(11):e78980.

50. Wongkajornsilp A, Somchitprasert T, Butraporn R, Wamanuttajinda V, Kasetsinsombat K, Huabprasert S, et al. Human cytokine-induced killer cells specifically infiltrated and retarded the growth of the inoculated human cholangiocarcinoma cells in SCID mice. Cancer Invest. 2009;27(2):140-8.

51. Wongkajornsilp A, Sangsuriyong S, Hongeng S, Waikakul S, Asavamongkolkul A, Huabprasert S. Effective osteosarcoma cytolysis using cytokine-induced killer cells pre-inoculated with tumor RNA-pulsed dendritic cells. J Orthop Res. 2005;23(6):1460-6.

52. Schmeel LC, Schmeel FC, Coch C, Schmidt-Wolf IG. Cytokine-induced killer (CIK) cells in cancer immunotherapy: report of the international registry on CIK cells (IRCC). J Cancer Res Clin Oncol. 2015:141(5):839-49.

53. Bailey SR, Nelson MH, Himes RA, Li Z, Mehrotra S, Paulos CM. Th17 cells in cancer: the ultimate identity crisis. Front Immunol. 2014:5:276.

54. Kumar P, Subramaniyam G. Molecular underpinnings of Th17 immuneregulation and their implications in autoimmune diabetes. Cytokine. 2015; 71(2):366-76.

55. Burkett PR, Meyer zu Horste G, Kuchroo VK. Pouring fuel on the fire: Th17 cells, the environment, and autoimmunity. J Clin Invest. 2015;125(6):2211-9.

\section{Submit your next manuscript to BioMed Central and we will help you at every step:}

- We accept pre-submission inquiries

- Our selector tool helps you to find the most relevant journal

- We provide round the clock customer support

- Convenient online submission

- Thorough peer review

- Inclusion in PubMed and all major indexing services

- Maximum visibility for your research

Submit your manuscript at www.biomedcentral.com/submit

) Biomed Central 